\title{
Review on additive manufacturing of dental materials
}

\author{
Sun Won, Hyeon-Goo Kang, Kyung-Ho Ko, Yoon-Hyuk Huh, Chan-Jin Park, Lee-Ra Cho* \\ Department of Prosthodontics and Research Institute of Oral Science, College of Dentistry, Gangneung-Wonju National University, \\ Gangneung, Republic of Korea
}

Additive manufacturing (AM) for dental materials can produce more complex forms than conventional manufacturing methods. Compared to milling processing, AM consumes less equipment and materials, making sustainability an advantage. AM can be categorized into 7 types. Polymers made by vat polymerization are the most suitable material for AM due to superior mechanical properties and internal fit compared to conventional self-polymerizing methods. However, polymers are mainly used as provisional restoration due to their relatively low mechanical strength. Metal AM uses powder bed fusion methods and has higher fracture toughness and density than castings, but has higher residual stress, which requires research on post-processing methods to remove them. AM for ceramic use vat polymerization of materials mixed with ceramic powder and resin polymer. The ceramic materials for AM needs complex post-processing such as debinding of polymer and sintering. The low mechanical strength and volumetric accuracy of the products made by AM must be improved to be commercialized. AM requires more research to find the most suitable fabrication process conditions, as the mechanical properties and surface of any material will vary depending on the processing condition. (J Dent Rehabil Appl Sci 2021;37(1):1-15)

Key words: additive manufacturing; polymer; metal; ceramic; mechanical properties

\begin{abstract}
서론
적층가공방식(additive manufacturing)은 3차원 프린 팅(3D printing)을 이용한 제작방식으로 현재 치과임상 에서 기존 제작방식의 한계를 보완하기 위하여 새롭게 각광받고 있는 분야이다. 3차원 프린팅은 컴퓨터를 이용 하여 3 차원 모델을 디자인한 후 재료를 적층하여 제작한 다. ${ }^{1}$ 여러 분야에서 금속, 폴리머, 복합레진, 세라믹과 생 물학적인 재료까지 다양한 종류의 재료가 시도되고 있 다. ${ }^{2}$ 이러한 개발성과를 바탕으로 치과임상 분야에서도 기존의 주조방식과 CAD-CAM 절삭가공방식(computer aided design-computer aided manufacture subtractive manufacturing)을 대체하고자 많은 연구 및 개발이 이루

\footnotetext{
${ }^{*}$ Correspondence to: Lee-Ra Cho

Professor, Department of Prosthodontics and Research Institute of Oral Science, College of Dentistry, Gangneung-Wonju National University, 7 Jukheon-gil, Gangneung-si, Gangwon-Do, 25457, Republic of Korea

Tel: +82-33-640-3153, Fax: +82-33-640-3103, E-mail: lila@gwnu.ac.kr Received: January 4, 2021/Last Revision: January 19, 2021/Accepted: January 25, 2021
}

어지고 있다. 적층가공방식은 주조방식에 비해 제작과정 과 시간을 감소시키고 오차가 작으며, 절삭가공방식에 비해 기구 마모, 재료 소모 등을 극복할 수 있는 생산적 인 방식이다. ${ }^{1}$

적층가공방식에 쓰이는 치과용 재료는 현재 폴리머 분 야에서 주로 많은 연구가 이루어져 있고, 그 결과를 바 탕으로 치과용 모형제작과 맞춤형 트레이, 교정장치, 임 플란트 수술용 가이드, 총의치의 인공치아 제작, 임시수 복물 제작 등 다양한 분야에 걸쳐 연구되고 사용되고 있 다. ${ }^{3}$ 금속이나 세라믹 분야는 재료 자체의 우수한 물리적 성질 및 심미성 등으로 많은 연구가 진행되고 있지만 제 작방식 및 조건이 까다롭고 제작된 구조의 표면 마무리 (surface finishing)나 물리적 성질, 체적정확성 등의 한계

Copyright $(2021$ The Korean Academy of Stomatognathic Function and Occlusion. (c) It is identical to Creative Commons Non-Commercial License. 
와 문제점이 있어 아직은 연구단계에 그치고 있지만, ${ }^{4}$ 공 정조건을 개선하여 상용화하려는 시도가 많이 이루어진 다. 적층가공이 보다 활성화되려면 그 장점과 한계를 명 확히 알아야 한다.

\section{문헌고찰}

\section{치과용 재료의 적층가공제작}

적층가공방식은 The American Section of the International Association for Testing Materials (ASTM)에서 7가지 방식으로 정의하고 있으며, ${ }^{5}$ 각각의 세부 구분을 Table 1에 정리하였다. 치과용으로 주로 사용되는 방식 은 fused deposition modeling (FDM), stereolithography (SLA), digital light projection (DLP), material jetting (MJ) 등이다. ${ }^{3}$

치과용 폴리머 재료의 제작에는 주로 SLA와 DLP 방 식이 주로 사용되는데, 이 두 방식은 제작과정이 거의 유 사하다. SLA 방식은 액상의 광중합개시제를 함유하여 광중합이 가능한 단량체(photo-polymerizable monomer)에 특정 파장의 광원(주로 자외선)을 조사해 선택적 으로 중합시켜 한 단면의 폴리머사슬을 완성하고 다른 단면으로 이동하여 중합시키는 방식을 반복하고 각 층 을 결합시킴으로써 제작하고자 하는 구조를 완성하는 원 리이다. ${ }^{6,7}$ 중합의 정도는 광중합개시제와 광조사 조건(파 장, 출력, 노출시간 및 속도), 첨가된 성분 등의 영향을 받 게 된다. ${ }^{8-10} \mathrm{SLA}$ 방식을 이용하면 마이크로미터 단위의 표면조도를 가지는 질 높은 표면을 얻을 수 있다. DLP방
식과 SLA방식의 가장 큰 차이점은 광원이다. ${ }^{5} \mathrm{DLP}$ 방식 은 초소형 거울이 신호에 따라 반사각을 조절하여 선택 적으로 광중합함으로써 구조를 완성한다. ${ }^{11,12}$ 현재까지 개발되어 구강 내에서 사용이 가능한 시판 제품 폴리머 들이 존재하지만 제조사에서는 대부분 그 구성성분에 대 해서는 자세히 밝히고 있지 않다. ${ }^{13}$

금속재료의 적층가공법은 폴리머 재료 다음으로 많이 연구된 분야이다. 주로 powder bed fusion (PBF)와 direct energy deposition (DED) 방식이 사용된다. 적층가 공이 가능한 금속은 티타늄과 그 합금, 귀금속 합금, 코 발트-크롬(Co-Cr) 합금 등이다. ${ }^{14}$

세라믹의 적층가공방식은 아직 연구 단계에 있는 분야 이다. 세라믹은 우수한 물리적 성질과 열 및 화학적 안정 성, 우수한 광학적인 성질, 생체적합성, 심미성 등의 여러 가지 우수한 장점을 가지는 재료로, 잠재성이 우수한 적 층가공용 재료로 주목받고 있다. CAD-CAM을 이용한 절삭가공방식을 이용한 지르코니아 고정성 보철물이 현 재 임상에서 가장 일반적으로 쓰이고 있으나 제작과정 에서의 한계점이 존재한다. 절삭방식으로 제작하기 때문 에 버려지는 원재료의 양이 많고, 블록의 강한 강도에 의 해서 절삭기구의 마모가 발생하여 잦은 교체가 필요하 며, 절삭기계의 축이나 버 크기의 한계로 재현할 수 있는 표면의 한계가 존재하며 절삭과정에서 발생한 미세파절 이 표면의 질을 저하시킬 가능성이 존재한다. ${ }^{12,15-17}$ 반면, 적층가공법은 세밀하고 복잡한 부위까지 표현이 가능하 고 제작단계가 상대적으로 단순하여 제작시간을 줄일 수 있고 제작과정에서의 오류를 최소화할 수 있으며, 낭비 되는 원재료가 상대적으로 적고 쓰이는 장비의 마모 및

Table 1. Classification of additive manufacturing methods suggested by ASTM

\begin{tabular}{ll}
\hline \multicolumn{1}{c}{ Classification } & \multicolumn{1}{c}{ Additive manufacturing methods } \\
\hline Vat polymerization & Stereolithography (SLA) \\
& Direct light processing (DLP) \\
Material jetting (MJ) & Direct inkjet printing \\
Material extrusion & Fused deposition modeling (FDM) \\
& Robocasting \\
Binder jetting (BJ) & \\
Powder bed fusion (PBF) & Selective laser sintering (SLS) \\
& Selective laser melting (SLM) \\
Sheet lamination & Electron beam melting (EBM) \\
Direct energy deposition (DED) & Direct energy deposition (DED) \\
& Hybrid fused deposition modeling (FDM) \\
\hline
\end{tabular}


교체가 덜 필요하므로 제작과정의 지속가능성이 우수하 다. ${ }^{4}$

\section{임시수복용 폴리머의 적층가공}

치과영역에서 폴리머를 이용하여 제작한 적층가공방 식은 상대적으로 가장 많이 연구되고 개발된 분야로, 악 안면보철, 의치상 및 인공치아 제작, 임시수복물이나 치 과용 모형 제작, 임플란트 수술 가이드, 교정용 장치 등 의 분야에서 임상적으로 널리 사용되고 있다. ${ }^{18}$ 임시수복 물은 보철수복 과정에서 지대치와 주변 연조직의 생물학 적, 물리적 보호와 위치 안정의 역할을 하며, 심미, 교합, 발음 등의 진단 및 치료계획의 평가에 중요한 역할을 하 고, 최종보철 완성 전까지 치아 상실에 따른 환자의 심리 적인 안정을 유도하는 역할도 한다. ${ }^{18,19}$

치과용 임시수복재료는 화학적 구성 성분에 따라서 크 게 두 종류로 분류할 수 있다. 이는 monomethacrylates (MMA) 혹은 아크릴레진 계열과 dimethyacrylates 혹은 bis-acryl/composite resin계열이다(Table 2). ${ }^{20}$ 최근에는 임시수복에도 $\mathrm{CAD}-\mathrm{CAM}$ 을 이용한 절삭가공방식이 많 이 사용되고 있다. 전통적인 제작방식에 비해서 높은 밀 도와 중합률을 가진 레진블록을 절삭하여 가공하기 때 문에 더 우수한 물리적 성질과 높은 정확도를 얻을 수 있 다. 그러나 앞서 언급한 대로, 절삭가공방식의 한계점과 적층가공방식의 발달로 이를 대체하기 위한 연구 및 개 발이 이루어지고 있다. 레진 폴리머 계열은 적층가공 방 식의 재료로 가장 많이 연구된 분야로 치과임상분야에 적용이 확대되고 있다. 이 중 polymethylmethacrylate (PMMA) 계열은 전통적인 제작방식뿐 아니라 이를 대체 하기 위한 절삭가공 및 적층가공 임시수복재료로도 가장 일반적으로 사용되고 있다. 전통적인 방식의 직접법을 통 한 자가중합형 PMMA 임시수복물 제작은 저렴한 비용, 제작 용이성 때문에 가장 널리 쓰이지만, 중합수축과 변 연부적합, 발열반응 및 잔류단량체에 의한 위해 가능성 등의 단점이 존재한다. 또한 장기적인 사용을 위해서는 높은 강도와 색조안정성이 중요한데, 장기적 안정성 측
면에서도 적절하지 못하다. 이러한 단점을 보완할 수 있 는 방법이 절삭가공 혹은 적층가공 제작방식인데, 내면 적합 및 변연적합이 우수하고, 간접법으로 제작하기 때 문에 중합수축이나 잔류단량체에 의한 위해가능성이 적 다. 또한 높은 중합률을 통해 더 높은 강도와 색조안정성 을 갖는 임시수복물을 제작할 수 있어 장기적 사용에 적 절하다. ${ }^{19,21}$

치과용 폴리머 소재 임시수복물의 제작은 주로 SLA, DLP방식이 주로 사용되고 있다. 여러 문헌에서 새롭게 제안되고 있는 적층가공방식과 전통적인 자가중합 제작 방식과 CAD-CAM을 이용한 절삭가공방식을 비교하고 있다. 이미 임상 사용승인을 받아 실제로 사용되고 있는 제품들이 존재하나 제조사에서 구성성분에 대해서 구체 적으로 밝히지 않고 있는 경우가 대부분이고, 물리적인 특성이나 적합도, 정확도 등에 대해 평가하고 있는 연구 는 상대적으로 적은 편이다. 이는 최종수복재에 비해 상 대적으로 그 중요성이 낮게 평가되기 때문으로 생각되 나, 성공적인 보철수복을 위해서는 임시수복물의 역할도 중요하다.

살펴본 문헌들에 등장한, 현재 시판 중인 적층가공용 폴리머 계열의 임시수복재와 물성을 정리해보면 다음과 같다(Table 3).

관련된 최근 연구들을 살펴보면, Reeponmaha 등른 대구치 임시수복물 형태의 시편을 전통적인 자가중합방 식의 PMMA계열과 Bis-acryl계열 폴리머, CAD-CAM 절삭가공방식의PMMA 및 적층가공방식의 Freeprint Temp (Detax GmbH, Ettlingen, Germany)를 비교하 였다. 파절강도는 적층가공 및 절삭가공, 직접제작방식 의 Bis-acryl 계열이 전통적인 방식의 PMMA보다 유의하 게 높은 강도를 보였다. Tahayeri 등 ${ }^{23}$ 의 연구에서도 유사 한 결과를 확인할 수 있는데, 적층가공 방식인 NextDent C\&B (Vertex Dental B.V, Soesterberg, Netherlands)를 자가중합방식 Bis-acryl계열인 Integrity (DentsplySirona, Milford, USA)와 PMMA계열인 Jet (Lang Dental Inc., Wheeling, USA)와 비교하였다. 연구 결과, 적층가공한 시편이 자가중합 PMMA계열보다는 높은 탄성계수를 보

Table 2. Classification of materials for dental interim provisional restorations

\begin{tabular}{cc}
\hline Monomethacrylate or acrylic resin & Dimethyacrylate or bis-acryl/composite resin \\
\hline Polymethylmethacrylate (PMMA) & Bisphenol A-glycidyl dimethacrylate (Bis-GMA) \\
Polyethyl/butylmethacrylate (PEMA) & Urethane dimethacrylate (UDMA) \\
\hline
\end{tabular}


Table 3. Commercially used 3D printing materials for interim provisional restoration

\begin{tabular}{|c|c|c|c|c|}
\hline Manufacturer & Product name & Composition & $\begin{array}{c}\text { Flexural strength } \\
(\mathrm{MPa})\end{array}$ & Certification \\
\hline $\begin{array}{c}\text { Detax GmbH } \\
\text { (Ettilingen, Germany) }\end{array}$ & FreePrint Temp & $\begin{array}{l}\text { Photo-polymerized } \\
\text { bis-acrylate resin }\end{array}$ & $>100$ & $\begin{array}{c}\text { Class IIa } \\
\text { Not FDA-approved }\end{array}$ \\
\hline $\begin{array}{c}\text { DWS } \\
\text { (Vicenza, Italy) }\end{array}$ & Temporis & $\begin{array}{l}\text { Mixture of multi-functional } \\
\text { acrylic monomer, esters of } \\
\text { acrylic acid }\end{array}$ & $85-135$ & $\begin{array}{c}\text { Class IIa } \\
\text { Not FDA-approved }\end{array}$ \\
\hline \multirow[t]{2}{*}{$\begin{array}{l}\text { EnvisionTEC } \\
\text { (Dearborn, USA) }\end{array}$} & E-dent 100 & $\begin{array}{l}\text { Tetrahydrofurfuryl methacry- } \\
\text { late, urethane dimethacrylate, } \\
\text { phosphinoxide and multifunc- } \\
\text { tional acrylic resin }\end{array}$ & $>90$ & Class IIa \\
\hline & E-dent 400 & $\begin{array}{c}\text { Monomer based on acrylic } \\
\text { esters }\end{array}$ & 85 & $\begin{array}{c}\text { Class IIa } \\
\text { FDA-approved }\end{array}$ \\
\hline $\begin{array}{c}\text { Vertex Dental } \\
\text { (Soesterberg, Netherlands) }\end{array}$ & $\begin{array}{c}\text { Nextdent C\&B } \\
\text { C\&B MFH }\end{array}$ & Methacrylic oligomer & $\begin{array}{c}85-100 \\
100-130\end{array}$ & $\begin{array}{c}\text { Class IIa } \\
\text { FDA-approved }\end{array}$ \\
\hline $\begin{array}{c}\text { Stratasys } \\
(\text { Santa Clarita, USA) }\end{array}$ & $\begin{array}{l}\text { VeroGlaze, } \\
\text { ED620 }\end{array}$ & $\begin{array}{c}\text { Acrylic monomer } \\
\text { 2-propenoic acid, } \\
\text { exo-1,7,7-trimethylbicyclo[2.2.1] } \\
\text { hept-2-yl ester, acrylic oligomer }\end{array}$ & $80-110$ & $\begin{array}{l}\text { Up to } 24 \mathrm{~h} \text { in-mouth } \\
\text { Not FDA-approved }\end{array}$ \\
\hline $\begin{array}{c}\text { Dentis } \\
\text { (Daegu, Korea) }\end{array}$ & $\begin{array}{l}\text { Zmd1000B } \\
\text { temporary }\end{array}$ & Oligomer-based photopolymer & Not provided & Class I \\
\hline $\begin{array}{c}\text { Ray } \\
\text { (Seongnam, Korea) }\end{array}$ & Raydent C\&B & $\begin{array}{l}\text { Urethane acrylate polymer, } \\
\text { Bismethylene bismethacrylate, } \\
\text { 2-hydroxyethyl methacrylate }\end{array}$ & $>140$ & Class IIa \\
\hline
\end{tabular}

The food and drug administration (FDA) from the United States Department of Health and human services controls and supervises medical devices to determine if they are appropriate for commercial use. Similarly, the European Union (EU) used CE marking on medical devices that comply with EU regulations, enabling the commercialization of the product in the European countries (ISO 13485). 3D-printed provisional materials available on the market are CE-certified and/or FDA-approved. Class I CE certification means the lowest perceived risk. Class IIa CE certification generally constitutes low to medium risk, and these devices area certified to be installed within the body between 60 minutes and 30 days.

였고, 최대응력에서는 전통적인 제작방식의 Bis-acryl과 유 사하고 PMMA보다는 유의하게 높은 결과를 보였다. 성 분 측면에서 살펴보면, 적층가공방식의 NextDent $\mathrm{C} \& \mathrm{~B}$ 는 $90 \%$ 이상이 methacrylic oligomer로 다른 충전재(filler)를 많이 포함하고 있지 않음에도 불구하고, PMMA 계열보다 우수한 결과를 보였고 40\% 정도의 barium-boro-alumino silicate 유리질을 함유하는 Bis-acryl계열과 유사한 최대응 력을 보였다. 그러므로 적층가공 제작방식의 임시수복물 이 구강내 환경에 적합한 물리적 성질을 가진다고 하였 다. 반면에 Digholkar 등 ${ }^{18}$ 의 연구에서는 적층가공방식의 microhybrid-filled 복합레진을 절삭가공방식의 PMMA, 전통적인 자가중합방식의 PMMA와 비교하였는데, 적 층가공방식의 시편이 유의하게 낮은 굽힘강도를 보였다. Scotti 등 ${ }^{24}$ 은 자가중합 Bis-acryl 계열의 Protemp4 (3M ESPE, St. Paul, USA)와 복합레진인 Filtek Z350XT (3M $\mathrm{ESPE}$ )를 적층가공방식의 NextDent C\&B MFH (Vertex Dental B.V)와 비교하였는데, 굽힘강도는 복합레진인
Filtek Z350XT, 적층가공방식의 NextDent C\&B MFH, 자가중합 PMMA 순으로 높은 강도를 보였다. 또, 누프 경도(Knoop hardness)의 비교에서도 같은 순서의 결과 를 보였다. 그러나 평가항목 중 색조안정성 측면에서는 적층가공시편이 불량한 결과를 보였다. 이러한 색조안정 성은 중합률, 단량체의 극성, 교차결합의 양, 개시제, 입 자의 크기와 분포, 수분흡수, 단량체 전이, 색소의 안정성 등의 영향을 받는데, ${ }^{24}$ 적층가공 시편의 경우 낮은 충전 재 함량과 높은 유기기질 함유로 인해 상대적으로 소수 성 정도가 복합레진에 비해 덜하여 색조안정성의 차이를 보인다고 하였다. Jeong 등 ${ }^{25}$ 의 연구에서는 적층가공방식 PMMA 2종인 Nextdent C\&B와 ZMD-1000B Temporary (Dentis, Daegu, Korea)을 CAD-CAM 절삭가공방 식 PMMA 2종인 Yamahachi PMMA disk (Yamahachi, Aichi, Japan)와 Huge PMMA block (Huge, Shandong, China), 전통적인 방식의 PMMA 2종의 Jet와 Alike (COE, Alsip, USA), Bis-acryl 2종의 Luxatemp (DMG, 
Hamburg, Germany), Protemp 4와 파괴인성 및 전단강 도를 비교하였다. 파괴인성 결과를 살펴보면 CAD-CAM 절삭가공방식의 시편이 가장 높은 결과를 보였고, 적층 가공방식은 전통적인 방식의 Alike, Luxatemp와 유사한 결과를 보였다. 다양한 연구를 종합해 보면 연구방법에 따라 다른 결과를 보이나, 전반적으로 적층가공제작 방 식의 임시수복재는 절삭가공용 레진보다 낮지만 자가중 합레진보다는 높은 물리적 강도를 나타낸다. 이렇게 다 른 결과가 나오는 이유는 시효처리방법이나 실험방법과 실험에 사용된 재료에 차이가 있으며 특히 적층가공방식 은 제작방법에 따른 차이가 크게 영향을 미치기 때문이 라고 사료된다.

물리적 특성 외의 평가항목을 살펴보면, 임시수복물 의 성공적인 지대치 보호와 안정적인 유지를 위해 중요 한 수복물의 적합도나 정확성 등에 대한 실험과 주변 조 직에 대한 생물학적 영향을 평가하기 위해 정적법(sessile drop method)을 이용한 친수성 평가, 표면에너지 분석, Candida albicans 배양실험 등이 있었다..$^{19,21,26,27}$ Peng 등 ${ }^{19}$ 은 디지털 방식의 절삭가공, 적층가공방식이 자가중합형 보다 더 우수한 내면 및 변연적합도를 가진다고 하였으 며, Park 등 ${ }^{21}$ 은 적층가공방식의 적합도가 절삭가공방식 이나 자가중합방식보다 우수하다고 하였다. Alharbi 등 ${ }^{26}$ 은 변연형태에 따른 적합도를 비교하였는데, 변연형태보 다는 가공방식에 따른 차이가 더 컸으며 적층가공방식이 가장 우수한 적합도를 보인다고 하였다. 그 외에 적층하 는 층의 두께와 적층가공제작 방향에 따른 영향을 평가 하는 연구도 존재하였다. ${ }^{23,27} \mathrm{Shim}$ 등 $^{27}$ 은 적층가공방식 에 따른 표면성질을 연구하였는데 같은 체적을 적층하더 라도 적층하는 한 층의 면적이 작은 방식이 더 간편하고
표면의 질도 우수하여 미생물부착도 작다는 장점을 가지 지만 강도 측면에서는 불리하다고 하였다. 폴리머에 대 한 연구내용을 종합해 보면, 적층가공방식의 폴리머 레 진 계열은 상대적으로 많이 연구된 분야로 임시수복재로 사용하기에 적절한 물리적 강도 및 적합도를 가지므로 기존의 제작방식을 대체할 수 있을 것으로 보인다. 그러 나 적층방식의 특성 상, 적층두께나 방향과 같은 제작조 건에 따라 표면의 특성이 다르게 나타나게 되므로 구강 내 사용 시 치태침착이나 생체적합성에 영향을 줄 수 있 으므로 가장 적절한 제작조건을 찾기 위한 추가적인 연 구가 필요할 것으로 사료된다.

\section{금속의 적층가공}

가장 일반적으로 적층가공에서 연구되는 금속은 티 타늄(Ti-6Al-4V)과 $\mathrm{Co}-\mathrm{Cr}$ 이며 주로 $\mathrm{PBF}$ 방식으로 제 작한다. $\mathrm{PBF}$ 에는 전자빔 기반의 electron beam melting (EBM)과 레이저 기반의 SLS와 SLM이 있는데, 보철물 제작에는 레이저 기반의 PBF 방식이 주로 이용된다. SLS 를 이용하면 조사되는 레이저에 의해 제공되는 단위 면 적당 에너지의 정도에 기초하여 특정 영역에서 분말 입자 가 불완전 소결될 가능성이 있다. ${ }^{28,29}$ 더 일반적으로 사용 되는 방식이 SLM인데 고출력 레이저를 합금분말에 조사 하여 열을 전달하고 급속 용융 및 냉각시킨 후 층을 쌓아 올리는 방식으로 합금분말의 완전 용융이 가능하고 기포 가 거의 없는 고밀도 형상을 얻을 수 있다. 이는 본 연구 팀에서 찍은 주사전자현미경 사진으로도 확인할 수 있는 데, 주조법으로 제작된 $\mathrm{Co}-\mathrm{Cr}$ 에 비해 기포의 수가 매우 적고 크기가 작다(Fig. 1).
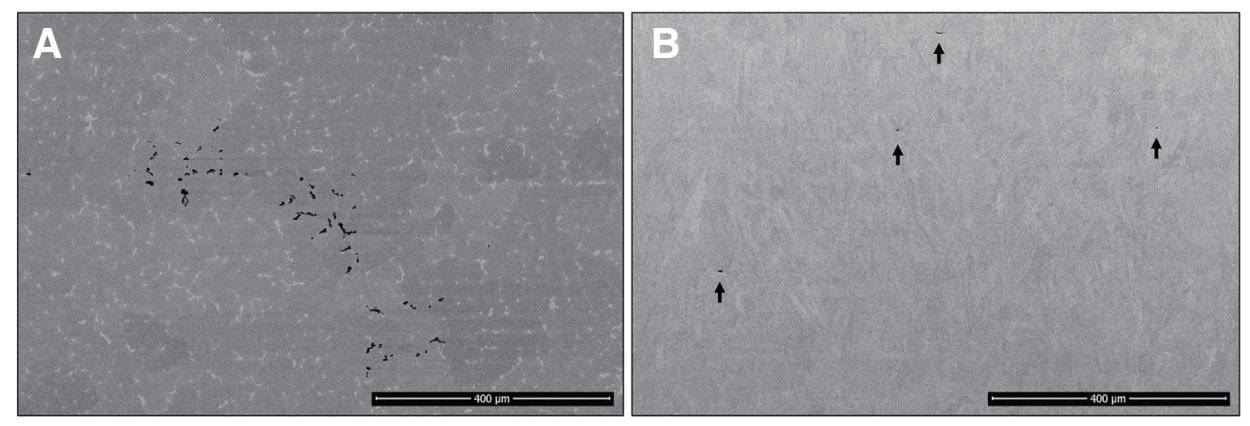

Fig. 1. Backscattered electron (BSE) images of the $\mathrm{Co}-\mathrm{Cr}$ alloys tested (original magnification $\times 200$ ). (A) Polished surface of Co-Cr alloy fabricated with casting, (B) Polished surface of Co-Cr alloy fabricated with SLM. Arrow heads indicate micro-porosities. Porosity (black area) appeared more in the casting method. 
Table 4. Mechanical properties of commercially available Co-Cr alloys fabricated with SLM

\begin{tabular}{|c|c|c|c|c|c|c|c|}
\hline \multirow[b]{2}{*}{ Brand } & \multicolumn{7}{|c|}{ Mechanical properties } \\
\hline & $\begin{array}{l}\text { Young's } \\
\text { modulus } \\
(\mathrm{GPa})\end{array}$ & $\begin{array}{l}\text { Tensile } \\
\text { strength } \\
(\mathrm{MPa})\end{array}$ & $\begin{array}{c}\text { Yield } \\
\text { strength } \\
0.2 \%(\mathrm{MPa})\end{array}$ & $\begin{array}{c}\text { Elongation } \\
\text { at break } \\
(\%)\end{array}$ & Hardness & $\begin{array}{l}\text { Density } \\
\left(\mathrm{g} / \mathrm{cm}^{3}\right)\end{array}$ & $\begin{array}{c}\text { Coefficient } \\
\text { of thermal } \\
\text { expansion } \\
\left(10^{-6} /{ }^{\circ} \mathrm{C}\right)\end{array}$ \\
\hline $\begin{array}{c}\text { EOS } \\
\text { MP1 } \\
\text { (EOS, Germany) }\end{array}$ & 200 & 1100 & 600 & 20 & $350-450 \mathrm{HV}$ & 8.3 & 13.6 \\
\hline $\begin{array}{c}\text { EOS } \\
\text { SP2 } \\
\text { (EOS, Germany) }\end{array}$ & 200 & 1350 & 850 & 3 & $420 \mathrm{HV}$ & 8.5 & $\begin{array}{l}14.3\left(500^{\circ} \mathrm{C}\right) \\
14.5\left(600^{\circ} \mathrm{C}\right)\end{array}$ \\
\hline $\begin{array}{c}\text { CoCr-0404 } \\
\text { (Renishaw, UK) }\end{array}$ & 220 & $1097-1104$ & $683-714$ & $16-21$ & $400-412 \mathrm{HV}$ & 8.5 & $14.1\left(600^{\circ} \mathrm{C}\right)$ \\
\hline $\begin{array}{l}\text { SLM }^{\circledR} \text { MediDent } \\
\text { (SLM Solutions, Germany) }\end{array}$ & 245 & 1415 & - & 4 & $375 \mathrm{HV}$ & - & - \\
\hline $\begin{array}{c}\text { 3D systems } \\
\text { ASTM F75 } \\
\text { (3D Systems, USA) }\end{array}$ & 230 & 1000 & 650 & 20 & $400 \mathrm{HV}$ & 8.35 & 14.3 \\
\hline $\begin{array}{c}\text { Concept Laser } \\
\text { (Concept Laser, Germany) }\end{array}$ & 230 & 1030 & 635 & 10 & - & 8.6 & $14.1\left(500^{\circ} \mathrm{C}\right)$ \\
\hline $\begin{array}{c}\text { Wirobond C+ } \\
\text { (BEGO, Germany) }\end{array}$ & 210 & $1150-1400$ & $790-1000$ & 9 & $360 \mathrm{HV}$ & 8.5 & 14.1 \\
\hline $\begin{array}{c}\text { Starbond COS } \\
\text { (Scheftner, Germany) }\end{array}$ & $195-200$ & $990-1250$ & - & $2-10$ & $345-490$ HV10 & 8.8 & $14.4\left(600^{\circ} \mathrm{C}\right)$ \\
\hline $\begin{array}{c}\text { Starbond Easy } 30 \\
\text { (Scheftner, Germany) }\end{array}$ & 225 & 1090 & - & 15 & 425 HV10 & 8.5 & $\begin{array}{l}14.5\left(500^{\circ} \mathrm{C}\right) \\
14.7\left(600^{\circ} \mathrm{C}\right)\end{array}$ \\
\hline $\begin{array}{c}\text { Remanium star CL } \\
\text { (Dentaurum, Germany) }\end{array}$ & 230 & $1136-1200$ & $792-835$ & $8-11$ & - & 8.6 & 14.1 \\
\hline
\end{tabular}

보철물 제작에는 SLM으로 제작된 $\mathrm{Co}-\mathrm{Cr}$ 이 가장 많이 이용되고, 현재 시판 중인 제품에 대한 물성비교를 시행 한 연구를 바탕으로, ${ }^{30}$ 기계적 특성을 정리해보면 다음과 같다(Table 4).

SLM으로 제작한 $\mathrm{Co}-\mathrm{Cr}$ 은 주조 $\mathrm{Co}-\mathrm{Cr}$ 에 비해 면심입 방(face centered cubic, FCC) $\gamma$ phase의 상분율이 더 높 기 때문에 강도뿐만 아니라 인성이 증가하고, 고용원소 의 고용한계가 증가하여 제 2 차 상 또는 금속간 화합물과 같은 석출물이 적으며, 균질하고 규칙적인 표면을 나타 내기 때문에 우수한 물성을 보인다. ${ }^{11,31}$ 전통적인 금속 제 작방식인 주조에 비해 SLM은 기공실 단계를 축소하여 생산 과정에 소요되는 비용이 저렴하고 재료낭비가 작으 며 재활용이 가능하다. 복잡한 구조재현이 가능하고 생 산력과 정확성 및 내면적합이 우수하지만 공정의 특성상 급속 가열과 냉각이 필요하여 잔류응력이 축적되어 물리
적 특성을 약화시킬 가능성이 있다. ${ }^{32}$ 미세구조 상 결정립 의 크기가 감소할 뿐만 아니라 일차 수지상 간격(primary dendrite spacing)이 주조에 비해 1/10 정도로 작기 때문 에 Hall Petch 효과에 의해 강도가 우수하다. ${ }^{33}$ SLM 방 식도 적층방향이나 적층높이와 같은 공정조건에 따라 물 성이 달라지며 다공성을 최소화하여 완전 밀도에 가깝 게 제작하는 공정을 개발하기 위한 연구가 진행되고 있 다. ${ }^{32,34}$ 무엇보다 결과물에 영향을 미칠 수 있는 잔류응 력을 최소화하기 위한 SLM 후 열처리가 중요하다. 동일 한 분말을 사용하여 금속도재관과 가철성 의치의 금속구 조물을 동시에 제작 후 열처리를 시행한 연구에서 열처 리는 금속과 도재의 결합강도에 영향을 미치지 않으면서 주조 금속구조물에 비해 높은 강도와 인성을 가지게 하 는 것으로 나타났다. ${ }^{35,36}$ 한편, 열처리를 하면 강도와 경 도의 변화는 연성의 변화와 반대의 경향을 나타내므로 ${ }^{11}$ 

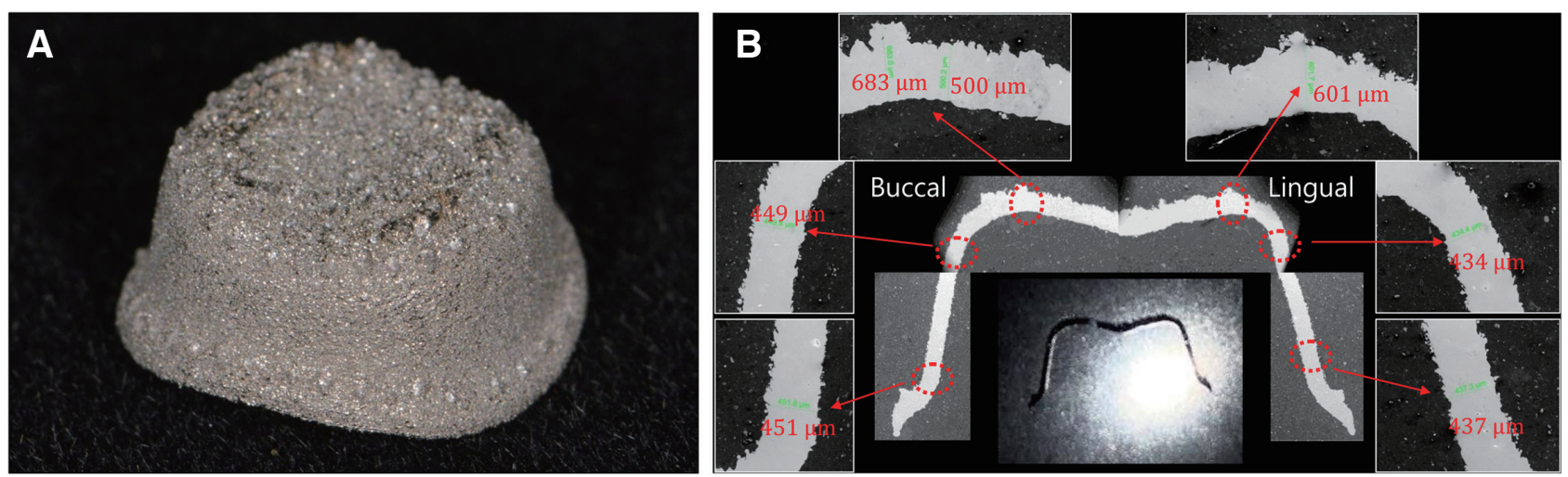

Fig. 2. As-built Co-Cr crown by SLM. (A) Rough surface by un-melted powders and remnants of support structure, (B) Different result of the printed wall thickness in crown specimen sectioned bucco-lingually. It was set to a constant thickness of $500 \mu \mathrm{m}$, however the thickness was small at the axial wall and large at the occlusal wall. Additionally, the occlusal surface was found to be coarser than the inner surface.

보철물에 필요한 정도의 물성을 가지도록 열처리 조건을 조절해야 한다. 잔류응력 외에 표면의 용융되지 않은 분 말에 의한 거친 표면조도와 낮은 체적 신뢰도와 같은 문 제도 나타난다(Fig. 2). 복잡한 보철물의 특성상 각각의 부위를 동시에 적절히 연마할 수 있는 방법은 아직까지 정립되어 있지 않고, 공정조건이 표면조도와 체적 정확성 에 영향을 미칠 수 있으므로 추가적인 연구가 필요할 것 으로 사료된다.

주조를 대체하기 위한 방법 중 절삭가공의 경우에 재 료소모와 절삭기구의 마모 및 유지비용이 높아 상업화되 기에는 한계가 있지만 금속 적층가공은 적용가능성이 더 높은 편이다. 하지만 현재의 제작방식으로 더 좋은 결과 물을 얻기 위해서는 잔류응력을 제거하고 우수한 미세구 조를 얻기 위한 열처리 방법이 개발되어야 하고, 거친 표 면을 위한 연마 방법과 높은 체적 정확도를 구현할 수 있 는 공정 조건에 대해 추가적으로 연구가 필요할 것으로 보인다.

\section{치과용 세라믹의 적층가공}

세라믹 소재의 적층가공방식은 1990년대에 처음 보고 되었다. ${ }^{37,38}$ 사용되는 세라믹 소재는 지르코니아 알루미 나, 리튬디실리케이트, 트리칼슘포스페이트 등이다. SLA 방식을 이용한 세라믹 소재의 적층가공방법은 주로 광 중합가능한 세라믹 현탁액(photopolymerizable ceramic suspension)을 이용하는데, 이는 광중합 레진에 세라믹 분말을 혼합한 것이다. 균질한 세라믹을 얻기 위해 고농
도의 액상 레진을 세라믹 현탁액과 혼합하여 적층가공 한 다음 광원으로 선택적으로 중합시키고 경화과정을 거 쳐 결과물을 얻게 된다. 이후 후처리과정으로 감광성 레 진 내의 유기물을 제거하는 과정이 필요하고 소결(sintering)과정을 거쳐야 밀도 높은 세라믹 수복물을 얻게 된 다. ${ }^{11,39-41}$ 하지만 실제 보철물을 제작하려면 까다로운 제 작조건을 엄격히 준수해야 하며 표면의 결함이나 기포 발생에 의한 낮은 물리적 강도, 체적정확성의 한계가 있 어 적절한 적층가공방식의 조건과 제작시편의 조건을 찾 기 위한 연구가 이루어지고 있다.

치과용 세라믹의 적층가공방식에 대한 최근 연구들을 살펴보면, 용기중합(vat polymerization)방식인 SLA나 DLP방식, 압출(material extrusion) 혹은 사출(material jetting)방식에 대한 연구가 많이 이루어지고 있다. ${ }^{42}$ 적층 가공된 결과물의 밀도, 파괴인성, 굽힘강도, 비커스 경도 등과 같은 물리적 성질에 대해 평가하는 연구가 많으며, 생체적합성과 심미성 등에 대한 평가를 위해 표면성분 분석과 젖음성, 불투명도, 세포배양실험 등에 대한 평가 도 이루어지고 있다. ${ }^{40-49}$ 다양한 적층가공방식과 세라믹 소재에 대한 연구들이 존재하나, 용기중합(SLA, DLP) 방식으로 제작한 치과용 세라믹과 관련된 최근 5년 이내 연구들을 위주로 살펴보면 다음과 같다. 제작조건에 대 한 연구는, $3 \mathrm{D}$ 프린터에서 세라믹 시편을 제작 시 설정한 단층두께(thickness of layer)의 경우 대부분의 연구에서 $100 \mu \mathrm{m}$ 이하로 제작하고 있었는데, 그 외에도 $20 \mu \mathrm{m}, 25$ $\mu \mathrm{m}, 50 \mu \mathrm{m}$ 의 단층두께를 설정하여 시편을 제작하여 비 교하는 연구도 있다. ${ }^{42-49}$ 
적절한 단층두께를 형성해야 우수한 표면을 얻을 수 있고 적절한 층 내, 층 간의 결합이 이루어져 안정적인 시 편의 제작이 가능하다. 단층의 두께를 두껍게 할수록 제 작시간이 단축되는 장점이 있으나, 삼차원적으로 디자인 한 모델을 특정한 두께의 이차원적 층으로 나누어 제작 하는 특성 때문에 '계단효과(ladder effect)'가 발생하여 층 간의 구분이 가능해지고 실제 디자인한 표면과 제작 된 표면 간의 차이가 발생하는 표면 질의 왜곡이 발생하 게 된다(Fig. 3). 이런 현상이 직접적으로 층간 박리현상 (delamination)을 유발하지는 않지만 단층의 두께가 두

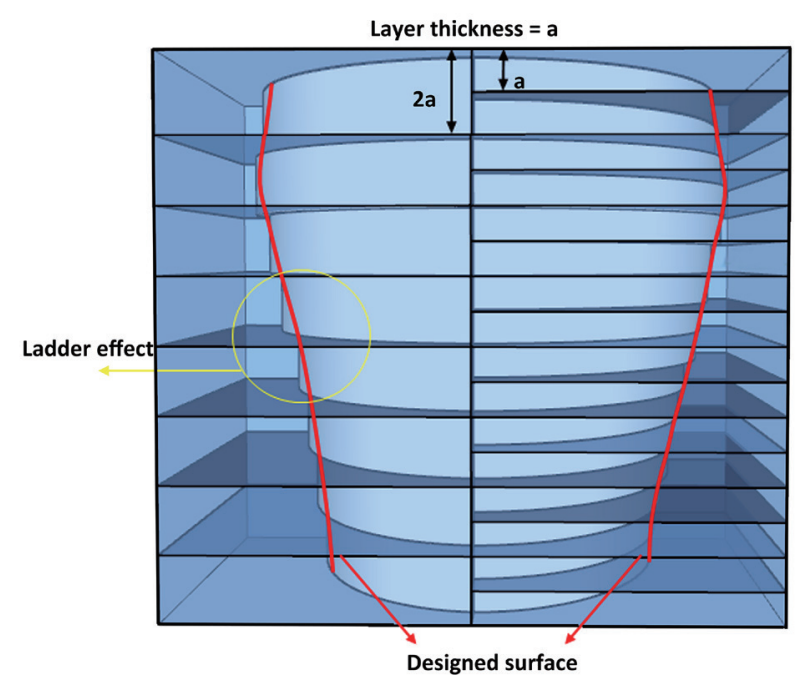

Fig. 3. Diagram for comparing surface quality with different condition of layer thickness (Left: 2a layer thickness, Right: a layer thickness), showing 'Surface deterioration' and 'Ladder effect'.
꺼운 경우 광원이 충분히 조사되지 않아 불충분한 중합 에 의해 층 간의 결합이 약해지게 되어 물리적 강도 저하 에 따른 보철물의 실패도 발생할 수 있다. 보철물로 사용 하려면 치수공차(dimensional tolerance)가 중요한데 너 무 큰 단층두께는 보철물의 부적합과 변연의 미세간극 이 발생할 가능성이 높아 임상 사용에 적절하지 않다. 단 층의 두께를 얇게 설정할수록 우수한 표면을 얻을 수 있 으며, 각 층의 완전한 중합을 이룰 수 있고, 층 경계 간의 기포나 박리현상을 예방할 수 있는 장점을 가지나, 제작 시간이 오래 걸리게 되어 생산성이 떨어지는 단점이 있 다. 44,48

적층가공방식 중 용기중합 방식의 특징으로, 각 층을 중합하면서 진행해 가는 제작방향(build-up orientation) 을 가지게 되는데, 제작방향의 설정에 따라서 하중에 의 해 시편이 받게 되는 응력이 다르게 작용하여 물리적 강 도에 영향을 미칠 수 있다. Marsico 등 ${ }^{48}$ 은 바 형태 시편 의 제작방향을 0 도, 45 도, 90 도로 다르게 설정하여 3 점 굽힘 강도실험을 하였다. 실험 결과 90 도의 제작방향으 로 제작된 시편은 하중의 방향이 층간 결합면 방향으로 작용하게 되므로 가장 낮은 강도를 보였고, 0 도 제작방 향의 경우 비교군으로 설정된 압착제작방식의 시편과 유 사할 정도로 높은 굽힘 강도를 보였다. Harrer 등 ${ }^{45}$ 은 파 절에 영향을 줄 수 있는 원인요소를 5 가지로 정의하였는 데, 이는 기포, 덩어리 뭉침(agglomerates), 세척잔사, 가 장자리 결함(edge damage), 절삭 결함(machining damage) 등이다(Fig. 4). 이러한 요소들이 힘의 작용방향에 따라서 다른 방식으로 영향을 미쳐 각각의 파절원인으로

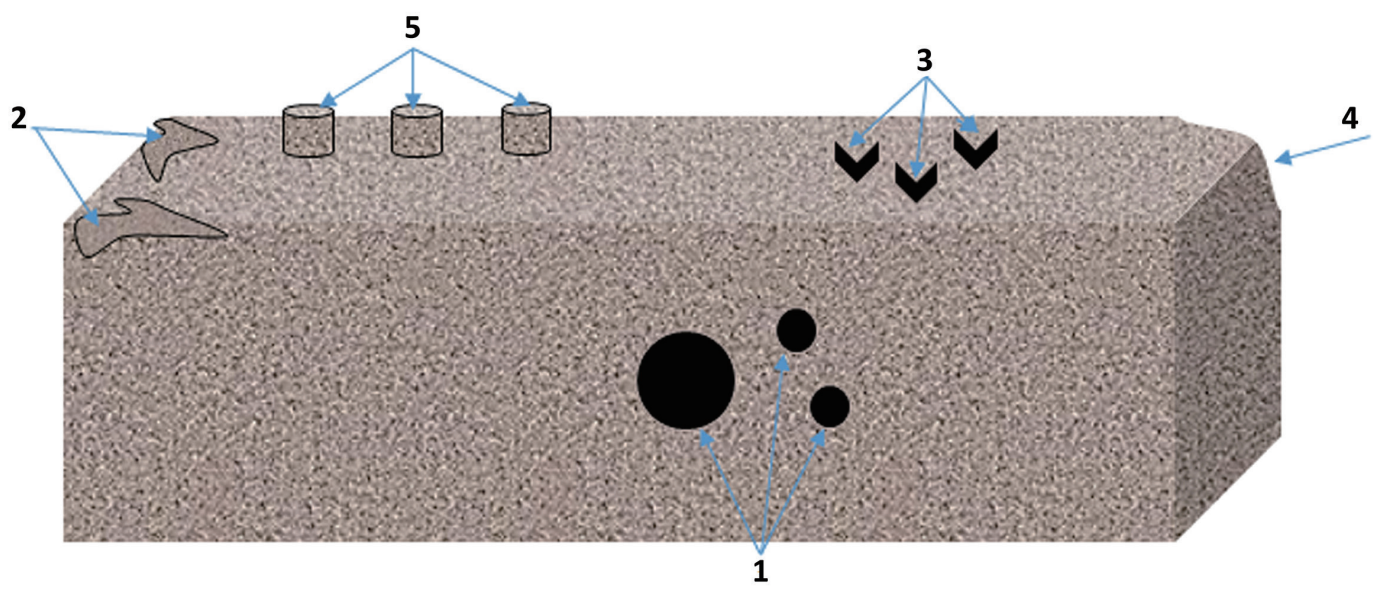

Fig. 4. Types of fracture inducing factors in additive manufacturing. 1) Pore; 2) Agglomerates of powder; 3) Cleansing defects; 4) Edge damage; 5) Machining damage. 
작용하였다. 이 중 가장 흔한 파절원인은 기포이며 분말 혼합 비율이 잘못되면 덩어리 뭉침이 발생하고 제작과정 에서 나머지 결함들이 발생할 수 있다.

이러한 결함은 어떤 방식으로 제작하는가 혹은 하중이 제작방향에 대해 어떤 식으로 작용하는가에 따라 다른 파절양상을 나타낼 수 있다(Fig. 5). 바 형태의 시편 제작 시, 같은 체적을 가지더라도 제작하는 방식은 3가지로 나 뉠 수 있다. 하중이 층간 결합면에 평행한 방향으로 작용 하는 2 가지 군과 층에 대해 수직적으로 하중이 작용하는 군에 대해 강도실험(ball-on-three balls, B3B)과 4점 굽힘 강도, 파괴인성 실험을 통해 물리적 강도와 파절양상을 분석하였는데, 시편의 제작방향에 따라 하중에 따른 응 력이 다르게 작용하여 시편 내에 존재하는 파절의 원인 요소들에 의해 파절양상에 차이가 있다고 하였다. ${ }^{45}$

3 가지 제작방식에서 파괴인성은 크게 차이가 나지 않 았으나 와이블계수는 $\mathrm{A}$ 가 가장 크고 $\mathrm{C}$ 가 낮았으며 A 시 편에서는 표면에 결함이 발생하는 반면 $\mathrm{B}$ 에서는 내부 기 포와 덩어리 뭉침이 많았다. 또한 시편의 층이 넓은 $\mathrm{C}$ 에
서 가장자리 결함이나 탈락이 많이 발생하였다. 다른 연 구들과 비교해도 $\mathrm{Harrer}^{45}$ 의 연구에서는 기포의 발생이 많은 편이었는데 이는 분말혼합 시 점도가 높아 공기방 울이 갇힌 것이 원인으로 사료된다. 따라서 점도조절을 위해 적층방식을 달리 하거나 진공으로 기포를 제거하는 방식 등 후처리에 대한 연구가 필요하다.

세라믹 소재의 적층가공은 세라믹 분말을 광중합이 가 능한 레진 폴리머와 혼합하여 만든 현탁액 상태에서 제 작한 후 유기물질을 제거하고 밀도를 증가시키는 후처 리과정과 같은 복잡한 과정을 거치게 된다. 제작에 사용 되는 세라믹 현탁액의 성분과 점도가 적층중합과정과 그 결과물에 중요한 영향을 미치는 요소 중 하나이다. 세라 믹 분말이 혼합된 현탁액은 그 유동학적 작용(rheological behavior)에 영향을 미치게 된다. 현탁액의 점도는 구 성성분의 고유한 성질과 양 및 세라믹의 입자크기에 의해 서 결정된다. ${ }^{11,50}$ Chartier 등 ${ }^{51}$ 의 연구에서는 세라믹 현탁 액의 분말구성비가 $50 \mathrm{vol} \%$ 이상이 되어야 열처리과정 에서의 변형과 균열생성을 피할 수 있다고 하였으나, 한편

\section{BS-upright (B)}
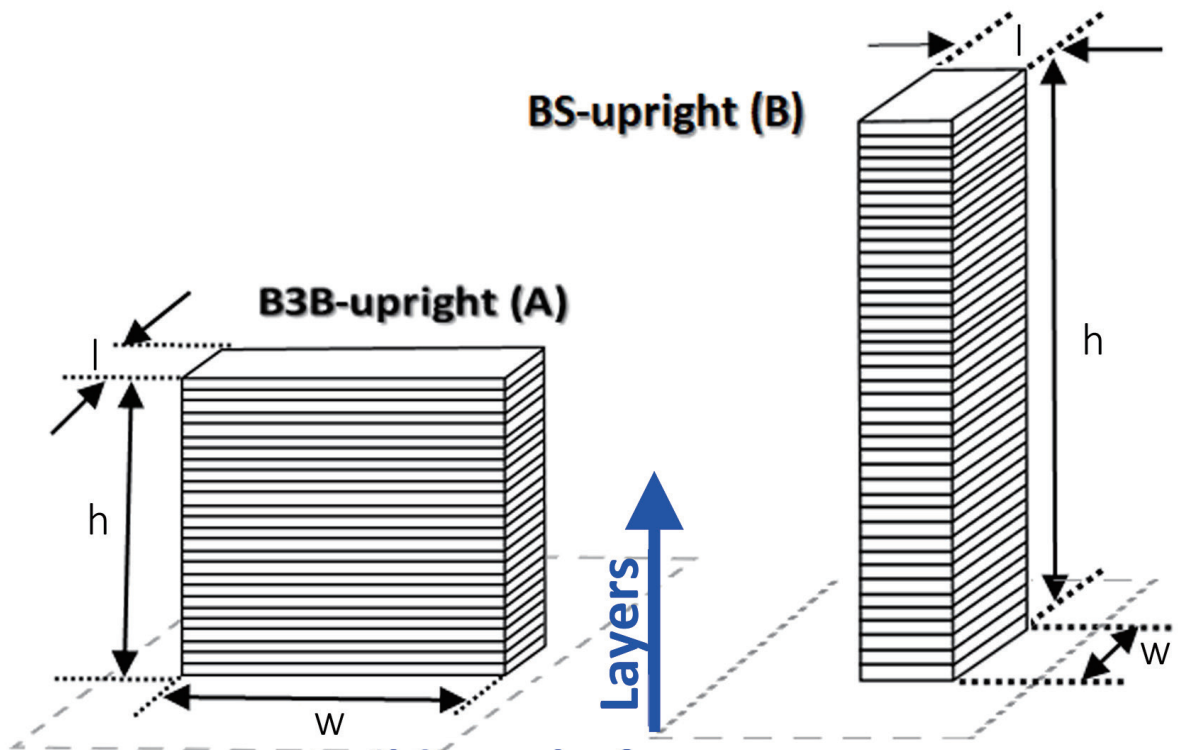

Buildíng platform

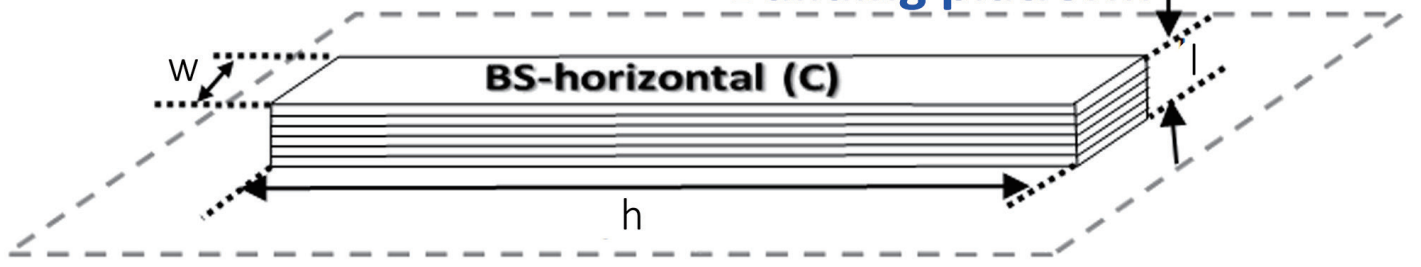

Fig. 5. Three different types of fabrication showing the different layer architecture. (A) Printed specimen with a long $x$-axis and parallel to the surface of the fracture test. (B) Printed specimen with a long $y$-axis and parallel to the surface of the fracture test. (C) Printed specimen perpendicular to the surface of the fracture test (h: height, w: width, I: length). 
으로 높은 분말구성비는 점도를 증가시키는 역할을 하여 가공과정에 어려움을 유발할 수 있다고 하였다. 따라서 분말구성비는 높으면서 낮은 점도를 갖게 하는 것이 SLA 제작방식에서 중요한 요인이 된다. Dehurtevent 등 $^{52}$ 은 SLA 제작방식으로 알루미나 시편을 제작할 때의 알루미 나 분말입자의 크기 $(0.46 \mu \mathrm{m}, 1.58 \mu \mathrm{m})$ 와 분말구성비(70 $\mathrm{wt} \%, 75 \mathrm{wt} \%, 80 \mathrm{wt} \%)$ 에 따른 물리적 성질을 비교하였 다. 입자 크기가 작을수록, 분말구성비가 커질수록 점도 가 증가하고 물리적 강도도 증가하는 경향을 보이지만, 작은 크기의 입자에서 일정 분말구성비 이상 $(\geq 75 \mathrm{wt} \%)$ 인 경우 시편 제작 시 변형이 관찰되었다. 최적의 조건은 큰 입자 크기 $(1.58 \mu \mathrm{m})$ 와 $80 \mathrm{wt} \%$ 분말구성비로, 이 조건 에서 제작된 시편에서는 밀도, 굽힘강도, 와이블 특성 등 의 물리적 성질이 비교군인 CAD-CAM 방식으로 제작된 In-Ceram Al blocks (Vita Zahnfabrik, Bad Säckingen, Germany)과 유사한 결과를 나타내었다. 세라믹 현탁액 의 온도에 따른 유동학적 작용에 대한 연구도 있는데, Baumgartner 등 $^{43}$ 은 SLA 방식으로 리튬디실리케이트 시 편을 제작하여 물리적 성질에 대해 평가하였다. 현탁액 의 온도를 $30^{\circ} \mathrm{C}$ 에서 $60^{\circ} \mathrm{C}$ 로 높이면 점도가 감소하여 제 작에 유리한 조건을 제공하였다. 세라믹 현탁액은 액체 인 레진과 고체인 세라믹 입자의 혼합액으로, 높은 온도 에서 액체상은 고체상과 달리 큰 열팽창이 일어나고, 그 결과 고체 입자의 부피비율이 감소하여 점도도 낮아지게 된다. 높은 점도를 가진 시편을 낮은 온도에서 제작할 때 일부 시편은 원래 형태가 아니라 표면부위가 작아지는 'cone end effect'가 발생하였는데, 이는 현탁액 내에 적 층가공된 시편이 잠겨 있는 동안 상분리현상이 발생하여 시편의 표면에서 고체상의 함유량이 증가하면서 발생하 는 것으로 보인다. 이처럼 현탁액의 점도와 분말함유량 뿐 아니라 온도 등과 같은 다양한 조건들이 변형을 최소 화할 수 있도록 적절하게 설정되어야 결과물의 물리적 성 질을 향상시킬 수 있다.

세라믹의 종류에 따라서도 제작조건 설정의 난이도와 제작결과가 다르게 나타난다. $\mathrm{Li}$ 등 ${ }^{44}$ 은 SLA 방식을 이용 한 지르코니아 보철물의 제작과정 전반에 대해서 평가 하였는데, 제작에 걸리는 시간의 측면에서 매개체 제거 와 소결과정, 세척 및 지지대(support structure)의 제거 와 같은 후처리 과정이 현재의 방식으로는 기존의 $\mathrm{CAD}$ $\mathrm{CAM}$ 방식의 지르코니아 보철물 제작에 비해 3 배 이상 의 시간이 소요된다는 점을 강조하면서 적층가공방식 의 장점이 크게 없으므로 지르코니아의 적층가공을 위해
제작시간을 줄이기 위한 노력이 필요하다고 하였다. 또 한 적층가공 제작과정에서 지지대의 디자인이 필수적이 고 이를 제거하고 연마하는 과정이 필요한데, 그 크기가 $800 \mu \mathrm{m}$ 정도로 크고 표면의 질과 심미성의 감소와 물리 적 강도 저하까지 일으킬 수 있어 임상사용에 있어 이 문 제의 해결 또는 고려가 반드시 필요하다고 하였다. 대부 분의 세라믹 적층가공이 알루미나나 지르코니아를 연구 한 반면 리튬디실리케이트에 대한 연구는 많지 않으나 지르코니아보다는 적층가공에 더 적합할 것으로 보인다. Baumgartner 등 $^{43}$ 은 리튬디실리케이트 시편을 적층가공 으로 제작하여 표면처리단계에 따라서 소환직후, 연마 및 글레이징 처리한 세 그룹으로 나누어 굽힘강도 실험 을 통해 물리적 강도를 평가하고 와이블 분석을 시행하 였다. 실험 결과, 굽힘강도를 비교하였을 때 연마처리 시 가장 강도가 높았고 그 다음이 글레이징이었으며 기존 제작방식의 리튬디실리케이트 보철물(IPS e. max Press, Ivoclar Vivadent, Schaan, Liechtenstein)의 와이블 계수 인 6 - 9와 유사하거나 높은 값을 보였다. 이 실험에서는 적층가공방식으로 높은 밀도와 적은 기포 및 결함을 가 져 우수한 물리적 성질을 나타내는 리튬디실리케이트 시 편을 제작할 수 있었고, 적층가공 후의 표면의 질에 따라 서 물리적 강도 및 보철물의 안정성이 영향을 받으므로 연마과정의 중요성을 확인하였다. 이상과 같이 용기중합 방식으로 제작된 치과용 세라믹 관련 연구들을 요약하여 정리하면 다음과 같다(Table 5).

\section{결론}

치과임상에 점차 활용도를 넓혀 가고 있는 적층가공제 작법은 다양한 방식이 개발되고 있으며 재료에 따라 적 절한 방식을 선택해야 한다. 폴리머 적층가공이 가장 많 이 연구되고 있으며 기존의 자가중합 방식보다 더 우수 한 물성과 적합도를 나타낸다. 세라믹 적층가공은 세라 믹 분말과 레진폴리머를 적층하는데 유기물 제거와 소 결 및 후처리 과정이 복잡하고 결과물의 물성이 기존 방 식에 비해 우수하지 않아 상용화되려면 해결해야 할 과 제가 많다. 금속 적층가공은 주조에 비해 우수한 물성을 얻지만 표면처리 및 잔류응력 해소를 위한 후처리조건 에 대한 연구가 필요하다. 어떤 재료이건 적층가공 공정 조건에 따라 물성이 달라지므로 최적의 공정조건을 찾기 위한 추가적인 연구가 필요하다. 
Table 5. Summary of reviewed literatures about additive manufacturing method of vat polymerization for dental ceramic

\begin{tabular}{|c|c|c|c|c|}
\hline Literatures & $\begin{array}{c}\text { AM } \\
\text { methods }\end{array}$ & Materials & Evaluation & Details \\
\hline Liu et al, $2016^{53}$ & SLA & $\begin{array}{l}\mathrm{Al}+\mathrm{Zr}^{4+} \\
\mathrm{Al}+\mathrm{Zr}^{4+} / \mathrm{Y}^{3+} \\
\mathrm{Al}+\mathrm{Mg}^{2+}\end{array}$ & $\begin{array}{l}\text { Fracture toughness } \\
\text { Vickers hardness }\end{array}$ & \\
\hline Johansson et al, $2016^{47}$ & DLP & $\mathrm{Al}$ & $\begin{array}{l}\text { Rheology } \\
\text { Shrinkage \% }\end{array}$ & Suspension composition \\
\hline Xing et al, $2017^{46}$ & SLA & $\mathrm{ZrO}_{2}$ & $\begin{array}{c}\text { 3-point flexural strength } \\
\text { Surface roughness } \\
\text { Vickers hardness } \\
\text { Fracture toughness }\end{array}$ & \\
\hline Harrer et al, $2017^{45}$ & SLA & 3Y-TZP & $\begin{array}{l}\text { B3B biaxial test } \\
\text { 4-point flexural strength } \\
\text { Fracture toughness } \\
\text { Weibull modulus } \\
\text { Vickers hardness }\end{array}$ & Build-up orientation \\
\hline Dehurtevent et al, $2017^{52}$ & SLA & $\mathrm{Al}$ & $\begin{array}{l}\text { Dynamic viscosity } \\
\text { 3-point flexural strength } \\
\text { Weibull modulus } \\
\text { Shrinkage } \%\end{array}$ & $\begin{array}{l}\text { Al powder particle size } \\
\text { Dry matter content }\end{array}$ \\
\hline Wang et al, $2018^{54}$ & SLA & $\mathrm{ZrO}_{2}$ & $\begin{array}{l}\text { Accuracy } \\
\text { Trueness }\end{array}$ & \\
\hline Uçar et al, $2018^{55}$ & SLA & $\mathrm{Al}$ & $\begin{array}{l}\text { Biaxial flexural strength } \\
\text { Fracture toughness } \\
\text { Vickers hardness } \\
\text { Weibull modulus }\end{array}$ & \\
\hline Lian et al, $2018^{56}$ & SLA & 3Y-TZP & $\begin{array}{l}\text { Vickers hardness } \\
\text { 3-point flexural strength } \\
\text { Surface roughness } \\
\text { Shrinkage } \%\end{array}$ & $\begin{array}{l}\text { Effect of vacuum infiltration } \\
\qquad \& \\
\text { Scanning speed }\end{array}$ \\
\hline Zandinejad et al, $2019^{57}$ & SLA & 3Y-TZP & $\begin{array}{l}\text { Fracture resistance } \\
\text { Mode of failure }\end{array}$ & \\
\hline Marsico et al, $2020^{48}$ & DLP & $\begin{array}{l}5.3 \mathrm{~mol} \% \mathrm{Y}_{2} \mathrm{O}_{3-}^{-} \\
\text {stabilized } \mathrm{ZrO}_{2}\end{array}$ & $\begin{array}{l}\text { Vickers hardness } \\
\text { Fracture toughness } \\
\text { Flexural strength } \\
\text { Weibull modulus } \\
\text { Elastic modulus }\end{array}$ & $\begin{array}{l}\text { Build-up orientation } \\
\left(0^{\circ}, 45^{\circ} \mathrm{A}, 45^{\circ} \mathrm{B}, 90^{\circ}\right)\end{array}$ \\
\hline Li et al, $2020^{44}$ & SLA & 3Y-TZP & $\begin{array}{c}\text { Shrinkage } \% \\
\text { Dimensional accuracy }\end{array}$ & $\begin{array}{c}\text { Consideration in the process } \\
\text { of manufacturing }\end{array}$ \\
\hline Baumgartner et al, $2020^{43}$ & DLP & Lithium disilicate & $\begin{array}{l}\text { B3B biaxial bending test } \\
\text { Fracture toughness } \\
\text { Vickers hardness } \\
\text { Weibull modulus }\end{array}$ & $\begin{array}{c}\text { Polishing / Glazing / } \\
\text { Layer thickness / } \\
\text { Suspension temperature }\end{array}$ \\
\hline
\end{tabular}

\section{ORCID}

Sun Won https://orcid.org/0000-0003-0514-6247

Hyeon-Goo Kang https://orcid.org/0000-0001-6293-0121

Kyung-Ho Ko https://orcid.org/0000-0002-1260-8844

Yoon-Hyuk Huh https://orcid.org/0000-0003-4072-5199

Chan-Jin Park https://orcid.org/0000-0003-4734-214X

Lee-Ra Cho https://orcid.org/0000-0003-3989-2870

\section{References}

1. Huang SH, Liu P, Mokasdar A, Hou L. Additive manufacturing and its societal impact: a literature review. Int J Adv Manuf Technol 2013;67:1191-203.

2. Guo N, Leu MC. Additive manufacturing: technology, applications and research needs. Front Mech Eng 2013;8:215-43. 
3. Jockusch J, Özcan M. Additive manufacturing of dental polymers: An overview on processes, materials and applications. Dent Mater J 2020;39:345-54.

4. Galante R, Figueiredo-Pina CG, Serro AP. Additive manufacturing of ceramics for dental applications: A review. Dent Mater 2019;35:825-46.

5. ASTM International. Standard terminology for additive manufacturing technologies. 2012.

6. Hull C. Apparatus for production of three-dimensional objects by stereolithography. US Patent 1986;638905.

7. Chen Z, Li Z, Li J, Liu C, Lao C, Fu Y, Liu C, Li Y, Wang P. He Y. 3D printing of ceramics: A review. J Eur Ceram Soc 2019;39:661-87.

8. Stansbury JW, Idacavage MJ. 3D printing with polymers: Challenges among expanding options and opportunities. Dent Mater 2016;32:54-64.

9. Infuehr R, Pucher N, Heller C, Lichtenegger H, Liska R, Schmidt V, Kuna L, Haase A, Stampfl J. Functional polymers by two-photon 3D lithography. Appl Surf Sci 2007;254:836-40.

10. Liska R, Cziferszky M, Inführ R, Turecek C, Fritscher C, Seidl B, Schmidt V, Kuna L, Haase A, Varga F, Lichtenegger HC, Stampfl J. Photopolymers for rapid prototyping. J Coat Technol Res 2007;4:50510.

11. Griffith ML, Halloran JW. Freeform fabrication of ceramics via stereolithography. J Am Ceram Soc 1996;79:2601-8.

12. Revilla-León M, Meyer MJ, Zandinejad A, Özcan M. Additive manufacturing technologies for processing zirconia in dental applications. Int J Comput Dent 2020;23:27-37.

13. Revilla-León M, Meyers MJ, Zandinejad A, Özcan M. A review on chemical composition, mechanical properties, and manufacturing work flow of additively manufactured current polymers for interim dental restorations. J Esthet Restor Dent 2019;31:517.

14. Ngo TD, Kashani A, Imbalzano G, Nguyen KT, Hui D. Additive manufacturing (3D printing): A review of materials, methods, applications and challenges. Compos B Eng 2018;143:172-96.

15. Strub JR, Rekow ED, Witkowski S. Computeraided design and fabrication of dental restorations: current systems and future possibilities. J Am Dent Assoc 2006;137:1289-96.

16. Beuer F, Schweiger J, Edelhoff D. Digital dentistry: an overview of recent developments for CAD-CAM generated restorations. Br Dent J 2008;204:505-11.

17. Lebon N, Tapie L, Duret F, Attal JP. Understanding dental CAD-CAM for restorations-dental milling machines from a mechanical engineering viewpoint. Part A: chairside milling machines. Int J Comput Dent 2016;19:45-62.

18. Digholkar S, Madhav VNV, Palaskar J. Evaluation of the flexural strength and microhardness of provisional crown and bridge materials fabricated by different methods. J Indian Prosthodont Soc 2016;16:328-34.

19. Peng CC, Chung KH, Yau HT, Ramos V Jr. Assessment of the internal fit and marginal integrity of interim crowns made by different manufacturing methods. J Prosthet Dent 2020;123:514-22.

20. Burns DR, Beck DA, Nelson SK, Committee on Research in Fixed Prosthodontics of the Academy of Fixed Prosthodontics. A review of selected dental literature on contemporary provisional fixed prosthodontic treatment: report of the Committee on Research in Fixed Prosthodontics of the Academy of Fixed Prosthodontics. J Prosthet Dent 2003;90:47497.

21. Park JY, Jeong ID, Lee JJ, Bae SY, Kim JH, Kim WC. In vitro assessment of the marginal and internal fits of interim implant restorations fabricated with different methods. J Prosthet Dent 2016;116:536-42.

22. Reeponmaha T, Angwaravong O, Angwarawong T. Comparison of fracture strength after thermomechanical aging between provisional crowns made with CAD-CAM and conventional method. J Adv Prosthodont 2020;12:218-24.

23. Tahayeri A, Morgan M, Fugolin AP, Bompolaki D, Athirasala A, Pfeifer CS, Ferracane JL, Bertassoni LE. 3D printed versus conventionally cured provisional crown and bridge dental materials. Dent Mater 2018;34:192-200.

24. Scotti CK, de Amoêdo Campos Velo MM, Rizzante FAP, de Lima Nascimento TR, Mondelli RFL, Bombonatti JFS. Physical and surface properties of a 3D-printed composite resin for a digital workflow. 
J Prosthet Dent 2020;124:614.e1-e5.

25. Jeong KW, Kim SH. Influence of surface treatments and repair materials on the shear bond strength of CAD/CAM provisional restorations. J Adv Prosthodont 2019;11:95-104.

26. Alharbi N, Alharbi S, Cuijpers VM, Osman RB, Wismeijer D. Three-dimensional evaluation of marginal and internal fit of 3D-printed interim restorations fabricated on different finish line designs. J Prosthodont Res 2018;62:218-26.

27. Shim JS, Kim JE, Jeong SH, Choi YJ, Ryu JJ. Printing accuracy, mechanical properties, surface characteristics, and microbial adhesion of 3D-printed resins with various printing orientations. J Prosthet Dent 2020;124:468-75.

28. Bae EJ, Kim JH, Kim WC, Kim HY. Bond and fracture strength of metal-ceramic restorations formed by selective laser sintering. J Adv Prosthodont 2014;6:266-71.

29. Kruth JP, Levy G, Klocke F, Childs THC. Consolidation phenomena in laser and powder-bed based layered manufacturing. CIRP Annals 2007;56:73059.

30. Zhou Y, Li N, Yan J, Zeng Q. Comparative analysis of the microstructures and mechanical properties of Co-Cr dental alloys fabricated by different methods. J Prosthet Dent 2018;120:617-23.

31. Kajima Y, Takaichi A, Kittikundecha N, Nakamoto T, Kimura T, Nomura N, Kawasaki A, Hanawa T, Takahashi H, Wakabayashi N. Effect of heat-treatment temperature on microstructures and mechanical properties of Co-Cr-Mo alloys fabricated by selective laser melting. Mater Sci Eng A 2018;726:2131.

32. Takaichi A, Suyalatu, Nakamoto T, Joko N, Nomura N, Tsutsumi Y, Migita S, Doi H, Kurosu S, Chiba A, Wakabayashi N, Igarashi Y, Hanawa T. Microstructures and mechanical properties of Co29Cr-6Mo alloy fabricated by selective laser melting process for dental applications. J Mech Behav Biomed Mater 2013;21:67-76.

33. Meacock CG, Vilar R. Structure and properties of a biomedical Co-Cr-Mo alloy producedby laser powder microdeposition. J Laser Appl 2009;21:88-95.

34. Tonelli L, Fortunato A, Ceschini L. CoCr alloy processed by Selective Laser Melting (SLM): effect of Laser Energy Density on microstructure, surface morphology, and hardness. J Manufac Process 2020;52:106-19.

35. Yan X, Lin H, Wu Y, Bai W. Effect of two heat treatments on mechanical properties of selectivelaser-melted Co-Cr metal-ceramic alloys for application in thin removable partial dentures. J Prosthet Dent 2018;119:1028.e1-e6.

36. Yan X, Xu YX, Wu Y, Lin H. Effects of heat treatment on metal-ceramic combination of selectivelaser-melted cobalt-chromium alloy. J Prosthet Dent 2018;120:319.e1-e6.

37. Beaman JJ, Barlow JW, Bourell DL, Crawford RH, Marcus HL, McAlea KP. Solid Freeform Fabrication: A New Direction in Manufacturing. Springer US, NY 1997.

38. Sachs E, Cima M, Williams P, Brancazio D, Cornie J. Three dimensional printing: rapid tooling and prototypes directly from a CAD model. J Manufac Sci Eng 1992;114:481-8.

39. Hinczewski C, Corbel S, Chartier T. Ceramic suspensions suitable for stereolithography. J Eur Ceram Soc 1998;18:583-90.

40. Doreau F, Chaput C, Chartier T. Stereolithography for manufacturing ceramic parts. Adv Eng Mater 2000;2:493-6.

41. Bertsch A, Jiguet S, Renaud P. Microfabrication of ceramic components by microstereolithography. J Micromech Microeng 2003;14:197-203.

42. Branco AC, Silva R, Santos T, Jorge H, Rodrigues AR, Fernandes R, Bandarra S, Barahona I, Matos APA, Lorenz K, Polido M, Colaço R, Serro AP, Figueiredo-Pina CG. Suitability of 3D printed pieces of nanocrystalline zirconia for dental applications. Dent Mater 2020;36:442-55.

43. Baumgartner S, Gmeiner R, Schönherr JA, Stampfl J. Stereolithography-based additive manufacturing of lithium disilicate glass ceramic for dental applications. Mater Sci Eng C Mater Biol Appl 2020;116:111180.

44. Li H, Song L, Sun J, Ma J, Shen Z. Stereolithography-fabricated zirconia dental prostheses: concerns based on clinical requirements. Adv Appl Ceram 2020;119:236-43.

45. Harrer W, Schwentenwein M, Lube T, Danzer R. 
Fractography of zirconia-specimens made using additive manufacturing (LCM) technology. J Eur Ceram Soc 2017;37:4331-8.

46. Xing H, Zou B, Li S, Fu X. Study on surface quality, precision and mechanical properties of $3 \mathrm{D}$ printed $\mathrm{ZrO} 2$ ceramic components by laser scanning stereolithography. Ceram Int 2017;43:16340-7.

47. Johansson E, Lidström O, Johansson J, Lyckfeldt O, Adolfsson E. Influence of Resin Composition on the Defect Formation in Alumina Manufactured by Stereolithography. Materials 2017;10:138.

48. Marsico C, Øilo M, Kutsch J, Kauf M, Arola D. Vat Polymerization-Printed Partially Stabilized Zirconia: Mechanical Properties, Reliability and Structural defects. Addit Manuf 2020;36:101450.

49. O’Masta MR, Stonkevitch E, Porter KA, Bui PP, Eckel ZC, Schaedler TA. Additive manufacturing of polymer-derived ceramic matrix composites. J Am Ceram Soc 2020;103:6712-23.

50. Chartier T, Badev A, Abouliatim Y, Lebaudy P, Lecamp L. Stereolithography process: influence of the rheology of silica suspensions and of the medium on polymerization kinetics-cured depth and width. J Eur Ceram Soc 2012;32:1625-34.

51. Chartier T, Dupas C, Lasgorceix M, Brie J, Champion E, Delhote N, Chaput C. Additive manufacturing to produce complex 3D ceramic parts. J Ceram Sci Technol 2014;6:95-104.

52. Dehurtevent M, Robberecht L, Hornez JC, Thuault A, Deveaux E, Béhin P. Stereolithography: A new method for processing dental ceramics by additive computer-aided manufacturing. Dent Mater 2017;33:477-85.

53. Liu W, Wu H, Zhou M, He R, Jiang Q, Wu Z, Cheng Y, Song X, Chen Y, Wu S. Fabrication of fine-grained alumina ceramics by a novel process integrating stereolithography and liquid precursor infiltration processing. Ceram Int 2016;42:1773641.

54. Wang W, Yu H, Liu Y, Jiang X, Gao B. Trueness analysis of zirconia crowns fabricated with 3-dimensional printing. J Prosthet Dent 2019;121:28591.

55. Uçar Y, AysanMeriç, Ekren O. Layered manufacturing of dental ceramics: fracture mechanics, micro- structure, and elemental composition of lithography-sintered ceramic. J Prosthodont 2019;28:e3108.

56. Lian Q, Sui W, Wu X, Yang F, Yang S. Additive manufacturing of $\mathrm{ZrO} 2$ ceramic dental bridges by stereolithography. Rapid Prototyp J 2018;24:114-19.

57. Zandinejad A, Methani MM, Schneiderman ED, Revilla-León M, Bds DM. Fracture Resistance of Additively Manufactured Zirconia Crowns when Cemented to Implant Supported Zirconia Abutments: An in vitro Study. J Prosthodont 2019;28:893-97. 


\section{치과용 재료의 적층가공에 대한 문헌고찰}

원선 대학원생, 강현구 전임의, 고경호 조교수, 허윤혁 부교수, 박찬진 교수, 조리라* 교수

강릉원주대학교 치과대학 보철학교실 및 구강과학연구소

치과용 재료의 적층가공제작은 기존 제작방식에 비해 복잡한 형태까지 제작할 수 있으며 절삭가공에 비해서도 기구나 재료의 소모가 적어 지속가능성이 장점으로 대두되고 있다. 적층가공 제작은 7 가지 방식으로 분류할 수 있는데, 폴리머 는 적층가공에 가장 적합한 재료로 용기중합방식으로 제작하며 기존 자가중합방식에 비해 높은 물성과 적합도를 가져 상용화에 더 적합하지만 상대적으로 낮은 강도로 인해 임시수복물로 주로 이용된다. 금속은 PBF (powder bed fusion) 방식을 주로 이용하며 주조방식에 비해 파괴인성과 밀도가 높지만 잔류응력이 높아 이를 제거하기 위한 후처리방식에 대한 연구가 필요하다. 세라믹은 분말과 레진폴리머를 혼합한 재료를 용기중합하는 방식이 일반적이다. 제작 후 폴리머 제거나 소결과 같은 후처리 과정이 복잡하다. 상용화되려면 세라믹 적층가공에 의한 결과물의 낮은 강도와 체적정확성 이 개선되어야 한다. 적층가공은 어떤 재료이건 공정조건에 따라 물성과 표면환경이 달라지므로 가장 적합한 공정조건 을 찾기 위한 연구가 더 많이 필요하다고 사료된다.

(구강회복응용과학지 2021;37(1):1-15)

주요어: 적층가공; 폴리머; 금속; 세라믹; 물성

*교신저자: 조리라

(25457) 강원도 강릉시 죽헌길 7, 강릉원주대학교 치과대학 치과보철학교실 및 구강과학연구소

Tel: 033-640-3153 | Fax: 033-640-3103 | E-mail: lila@gwnu.ac. kr

접수일: 2021년 1월 4일 | 수정일: 2021년 1월 19일 | 채택일: 2021년 1월 25일 